\title{
Ultrasonic Spray Pyrolysis Deposited Copper Sulphide Thin Films for Solar Cell Applications
}

\author{
Y. E. Firat, ${ }^{1}$ H. Yildirim, ${ }^{1}$ K. Erturk, ${ }^{2}$ and A. Peksoz ${ }^{1}$ \\ ${ }^{1}$ Physics Department, Sciences and Arts Faculty, Uludag University, Bursa, Turkey \\ ${ }^{2}$ Physics Department, Sciences and Arts Faculty, Namık Kemal University, Tekirdag, Turkey \\ Correspondence should be addressed to A. Peksoz; peksoz@uludag.edu.tr
}

Received 27 October 2015; Accepted 3 November 2016; Published 19 January 2017

Academic Editor: Brandon Weeks

Copyright (C) 2017 Y. E. Firat et al. This is an open access article distributed under the Creative Commons Attribution License, which permits unrestricted use, distribution, and reproduction in any medium, provided the original work is properly cited.

\begin{abstract}
Polycrystalline copper sulphide $\left(\mathrm{Cu}_{x} \mathrm{~S}\right)$ thin films were grown by ultrasonic spray pyrolysis method using aqueous solutions of copper chloride and thiourea without any complexing agent at various substrate temperatures of 240,280 , and $320^{\circ} \mathrm{C}$. The films were characterized for their structural, optical, and electrical properties by X-ray diffraction (XRD), scanning electron microscopy (SEM), energy dispersive analysis of X-rays (EDAX), atomic force microscopy (AFM), contact angle (CA), optical absorption, and current-voltage $(I-V)$ measurements. The XRD analysis showed that the films had single or mixed phase polycrystalline nature with a hexagonal covellite and cubic digenite structure. The crystalline phase of the films changed depending on the substrate temperature. The optical band gaps $\left(E_{g}\right)$ of thin films were $2.07 \mathrm{eV}(\mathrm{CuS}), 2.50 \mathrm{eV}\left(\mathrm{Cu}_{1.765} \mathrm{~S}\right)$, and $2.28 \mathrm{eV}\left(\mathrm{Cu}_{1.765} \mathrm{~S}-\mathrm{Cu}_{2} \mathrm{~S}\right)$. AFM results indicated that the films had spherical nanosized particles well adhered to the substrate. Contact angle measurements showed that the thin films had hydrophobic nature. Hall effect measurements of all the deposited $\mathrm{Cu}_{x} \mathrm{~S}$ thin films demonstrated them to be of p-type conductivity, and the current-voltage $(I-V)$ dark curves exhibited linear variation.
\end{abstract}

\section{Introduction}

Copper sulphide $\left(\mathrm{Cu}_{x} \mathrm{~S}\right)$ has attracted a great deal of scientific attention due to the tunable semiconductive properties and approximate metallic behaviors depending on stoichiometry of the mineral phase [1]. In a variety of techniques, it represents a promising p-type semiconductor used in a variety of technologies such as nanoscale electronic devices, cathode material of lithium ion batteries, chemical sensors, and especially photovoltaic cells because of its unique optical and electronic characteristics [2-7]. There are five stable phases of $\mathrm{Cu}_{x} \mathrm{~S}$ at room temperature which vary according to values of $x(1 \leq x \leq 2)$ : chalcocite $\left(\mathrm{Cu}_{2} \mathrm{~S}\right)$, djurleite $\left(\mathrm{Cu}_{1.95} \mathrm{~S}\right)$, digenite $\left(\mathrm{Cu}_{1.8} \mathrm{~S}\right)$, anilite $\left(\mathrm{Cu}_{1.75} \mathrm{~S}\right)$, and covellite $(\mathrm{CuS})[8,9]$. Because of these different phases, the energy band gap of $\mathrm{Cu}_{x} \mathrm{~S}$ thin films varies between 1.26 and $2.54 \mathrm{eV}$ [10-15].

Many studies have been carried out on $\mathrm{Cu}_{x} \mathrm{~S}$ films prepared by various techniques such as chemical vapor deposition (CVD) [16], RF sputtering [17], vacuum thermal evaporation [18], spray pyrolysis [19-21], and chemical bath deposition (CBD) [22]. Among these methods, ultrasonic spray pyrolysis (USP) is a suitable method for preparation of $\mathrm{Cu}_{x} \mathrm{~S}$ thin films [23-25]. The ultrasonic spray pyrolysis technique is a simple coating technology in which an aqueous solution containing compounds in the form of soluble salts of each element is sprayed onto heated substrates. In addition, this process also enables growth of easily nanostructured and high quality thin films and control of film thickness and stoichiometry. In this technique, inexpensive equipment is used, and high quality chemicals and substrates are not necessary compared with the other techniques. The USP is promising due to low cost, easy processability, and the possibility of fabricating large area films with satisfactory structural quality [26]. In USP technique, some parameters such as substrate temperature, molar ratio, type of salt, and $\mathrm{pH}$ of the solution change the physical properties of the thin films [27]. Crystalline structure, grain size, optical bad gap, semiconductor type, the ratio of elemental composition, and surface morphology of the deposited thin films can be configured by controlling these USP parameters.

In the present investigation, an attempt was made to deposit polycrystalline $\mathrm{Cu}_{x} \mathrm{~S}$ thin film of copper sulphide 
on glass substrates by ultrasonic spray pyrolysis method. Structural, morphological, electrical, and optical properties of copper sulphide thin films were investigated as a function of substrate temperature. Contact angle analysis of the copper sulphide film surfaces was performed depending on the substrate temperature for the first time. We try to explain crystalline phase transitions when the films are deposited at higher temperatures. To our knowledge, such a detailed study on the effect of substrate temperature on the properties of copper sulphide thin films is still lacking.

\section{Experimental Details}

2.1. Deposition of $C u_{x} S$ Thin Films. In the USP technique, a precursor aerosol is sprayed towards the substrate. The constituents in the precursor droplets interact to form a new chemical compound on the substrate surface. The physical properties of the deposited film vary depending on the composition of solution, spraying rate, substrate temperature, ambient atmosphere, carrier gas, droplet size, and the distance between spray nozzle and substrate. The $\mathrm{Cu}_{x} \mathrm{~S}$ films were deposited using an ultrasonic spray pyrolysis (USP) technique at different substrate temperatures. Details of the USP technique were described elsewhere [28]. Solution was prepared using a mixture of aqueous solutions of $0.01 \mathrm{M} \mathrm{CuCl}_{2} \cdot 2 \mathrm{H}_{2} \mathrm{O}$ and $0.05 \mathrm{M}$ thiourea, $\mathrm{CS}\left(\mathrm{NH}_{2}\right)_{2}$. Copper chloride (purity 99.9\%) and thiourea (purity 99.0\%) were purchased from Sigma-Aldrich. The films were deposited through ultrasonic nozzle onto microscope glass substrates (1 $\times 2 \mathrm{~cm}^{2}$ ) using air as the carrier gas with pressure of $1 \mathrm{~atm}$. The ultrasonic oscillator frequency was $100 \mathrm{kHz}$. Deposition time was $20 \mathrm{~min}$ and total solution sprayed onto substrates was 100 $\mathrm{cc}$. The solution flow rate was kept at $5 \mathrm{cc} / \mathrm{min}$ by a flowmeter. The distance from nozzle to substrate was kept constant at $36 \mathrm{~cm}$. The films were formed at three different substrate temperatures, 240,280 , and $320^{\circ} \mathrm{C}$. Substrate temperature was controlled by an iron-constant thermocouple within $\pm 5^{\circ} \mathrm{C}$. In this work, the thin films deposited at 240,280 , and $320^{\circ} \mathrm{C}$ substrate temperatures are called TF1, TF2, and TF3, respectively.

2.2. Thin Film Characterization. Characterization of the deposited films was performed using the appropriate techniques. PHE-102 Spectroscopic Ellipsometer (250-2300 nm) was used to measure thicknesses of the films. The X-ray diffraction (XRD) pattern was recorded using a Bruker D8 advanced diffractometer using $\mathrm{CuK}_{\alpha}$ radiation $(\lambda=$ $1.5406 \AA$ ) for $2 \theta$ values over $20-70^{\circ}$. The surface analysis of the thin films was performed in a Carl Zeiss EVO 40 type SEM (Carl Zeiss NTS Limited Company, Cambridge, UK) operated at $20 \mathrm{kV}$. The elemental analysis was performed in a Bruker AXS energy dispersive analysis of X-rays (EDAX) operated at $10 \mathrm{keV}$ with an XFlash 4010 detector. Before the analysis, the thin films were fixed on the specimen holder with an aluminum tape and mounted on an aluminum specimen holder. The surface morphology and roughness measurements were studied by atomic force microscope (AFM, Park Systems XE-70). The AFM images were taken in tapping mode with silicon cantilever (NSC16, force constant

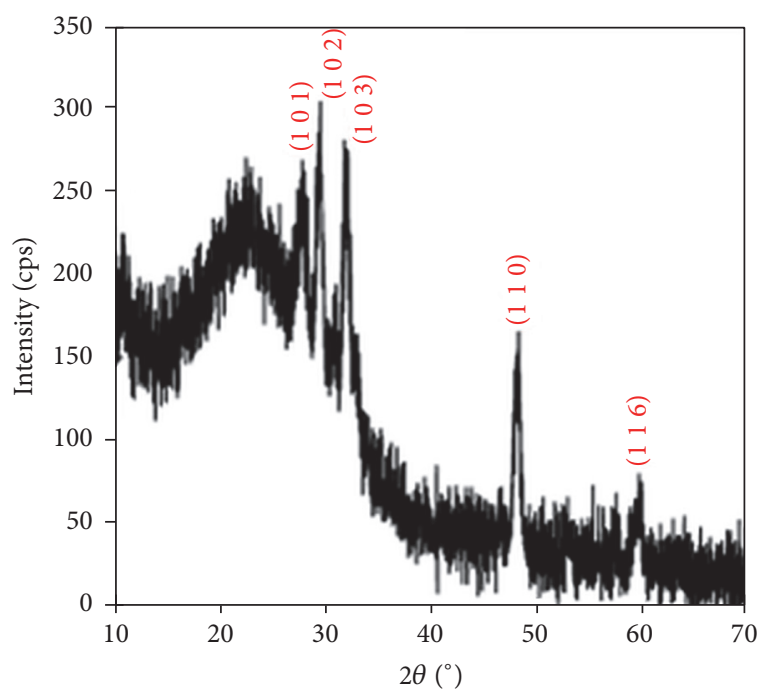

FIgURE 1: X-ray diffraction patterns of $\mathrm{Cu}_{x} \mathrm{~S}$ thin film (TF1) deposited at a substrate temperature of $240^{\circ} \mathrm{C}$. The diffraction planes were matched with JCPDS card number 6-0464.

$40 \mathrm{~N} / \mathrm{m}$, resonance frequency $150-190 \mathrm{kHz}$, and thickness $7.0 \mu \mathrm{m}$ ). The root mean square (RMS) roughness was calculated with the AFM software on images of $4 \times 4 \mu \mathrm{m}^{2}$ scan size. KSV Attention Theta instrument (Hamburg, Germany) was used to determine the contact angles (CA) of the $\mathrm{Cu}_{x} \mathrm{~S}$ thin films and glass substrate surfaces. Measurements were made in air at room temperature by the sessile drop technique with deionized water. The contact angles of the surfaces were measured via taking 10 separate photos from the different parts of surfaces. The transmittance and absorbance spectra for all the films were carried out using a Shimadzu-SolidSpec-3700 UV-VIS-NIR spectrophotometer. The electrical properties of the films, such as the carrier concentration, Hall mobility, Hall coefficient, and sheet resistance, were characterized by four-point probe and Hall effect measurements (HMS-3000 Manual Ver 3.5.1) at room temperature.

\section{Results and Discussion}

3.1. Structural Properties. The X-ray diffraction patterns (XRD) were recorded for all the films in the range of diffraction angle $2 \theta$ between 20 and $70^{\circ}$. Figures $1-3$ show XRD patterns of the $\mathrm{Cu}_{x} \mathrm{~S}$ thin films deposited on glass substrates at three different temperature conditions. The $\mathrm{X}$ ray diffraction pattern of these films revealed that these materials were polycrystalline phases: $\mathrm{CuS}, \mathrm{Cu}_{1.765} \mathrm{~S}$, and $\mathrm{Cu}_{2} \mathrm{~S}$.

Well-defined (1 001 1), (lll $\left.\begin{array}{lll}1 & 0 & 2\end{array}\right),\left(\begin{array}{lll}1 & 0 & 3\end{array}\right),\left(\begin{array}{lll}1 & 1 & 0\end{array}\right)$, and

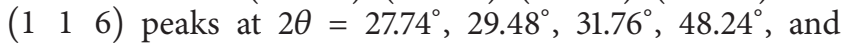
$59.64^{\circ}$ are observed in the XRD pattern due to hexagonal covellite phase of $\mathrm{CuS}$ (the lattice parameters are as follows: $a=b=3.792 \AA, c=16.344 \AA$ ) for the TF1, as shown in Figure 1. The result is in agreement with the data given in the work by Zhu et al. [29] and in standard values (JCPDS 60464). Figure 2 shows the XRD for the TF2. The diffractions peaks at $2 \theta$ values of $28.16^{\circ}, 32.26^{\circ}, 46.46^{\circ}$, and $54.8^{\circ}$ can 


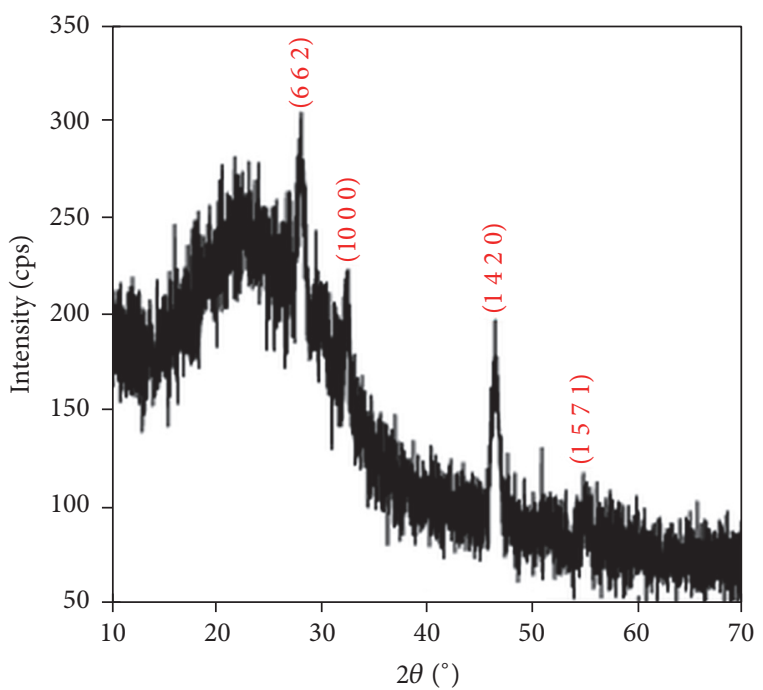

FIgURE 2: X-ray diffraction patterns of $\mathrm{Cu}_{x} \mathrm{~S}$ thin film (TF2) deposited at a substrate temperature of $280^{\circ} \mathrm{C}$. The diffraction planes were matched with JCPDS card number 23-0960.

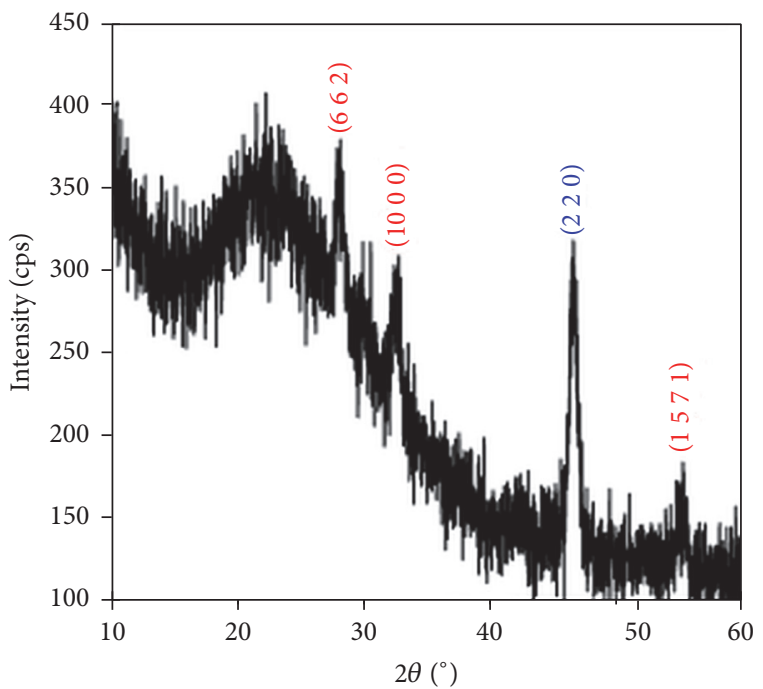

Figure 3: X-ray diffraction patterns of $\mathrm{Cu}_{x} \mathrm{~S}$ thin film (TF3) deposited at a substrate temperature of $320^{\circ} \mathrm{C}$. The diffraction planes were matched with JCPDS card numbers 2-1287 and 23-0960.

be indexed as ( $\left.\begin{array}{lll}6 & 6 & 2\end{array}\right),\left(\begin{array}{lll}10 & 0 & 0\end{array}\right),\left(\begin{array}{lll}14 & 2 & 0\end{array}\right)$, and $\left(\begin{array}{lll}15 & 7 & 1\end{array}\right)$ reflections of the cubic low digenite phase $\mathrm{Cu}_{1.765} \mathrm{~S}$ (the lattice parameters are $a=b=c=27.760 \AA$ ) for the TF2, which are well matched with the standard values (JCPDS 23-0960). As shown in Figure 3, the TF3 contains the mixed phase of hexagonal chalcocite $\left(\mathrm{Cu}_{2} \mathrm{~S}\right.$; the lattice parameters are $a=$ $b=c=5.562 \AA$, JCPDS 2-1287) and cubic low digenite phase $\left(\mathrm{Cu}_{1.765} \mathrm{~S}\right.$; the lattice parameters are $a=b=c=$ $27.760 \AA)$. The mixture peaks at $2 \theta=27.92^{\circ}, 32.44^{\circ}$, and $54.78^{\circ}$ are correlated with ( $\left(\begin{array}{lll}6 & 6 & 2\end{array}\right),\left(\begin{array}{lll}10 & 0 & 0\end{array}\right)$, and ( (15 $\left.7 \begin{array}{ll}15\end{array}\right)$ planes of $\mathrm{Cu}_{1.765} \mathrm{~S}$ and at $2 \theta=46.62^{\circ}$ are correlated with the $\left(\begin{array}{lll}2 & 2 & 0\end{array}\right)$ plane of $\mathrm{Cu}_{2} \mathrm{~S}$.
From the XRD patterns of the $\mathrm{Cu}_{x} \mathrm{~S}$ films, we conclude that the high substrate temperature leads to a phase transition from $\mathrm{Cu}_{1.765} \mathrm{~S}$ to $\mathrm{Cu}_{2} \mathrm{~S}$.

The broadness of the full width at half maximum (FWHM) of the main diffraction peak indicates the formation of nanocrystals [22]. The average crystallite size of the $\mathrm{Cu}_{x} \mathrm{~S}$ films for the peak with highest intensity can be estimated by using Scherrer's formula [30]:

$$
D=\frac{0.9 \lambda}{\beta \cos \theta},
$$

where $\lambda$ is the wavelength of $\mathrm{Cu}-\mathrm{K}_{\alpha}$ radiation (1.5406 $\AA$ ), $\beta$ is the broadening of diffraction line measured at half maximum intensity (in radians), and $\theta$ is the diffraction angle.

The crystallite size was calculated by using the wellknown Scherrer formula. The calculated crystallite size varies between $11.92 \mathrm{~nm}$ and $9.6 \mathrm{~nm}$ for TF1-TF3 materials (Table 1). The results indicate that crystallite size decreases as deposition temperature of the films increases.

3.2. Scanning Electron Microscopy and Energy Dispersive XRays Analysis. Figure 4 shows the surface characteristics of the $\mathrm{Cu}_{x} \mathrm{~S}$ thin films. These films are uniform, dense, and smooth and cover the glass substrate very well. A clear change in the surface formations of the thin films is seen when substrate temperature changes. In the first film, TF1, the surface shows large and small particles in different shapes, and there are no empty spaces between them (Figure 4(a)). The SEM image of TF2 (Figure 4(b)) demonstrates homogeneous distribution of the observed grains with dimensions on the order of $400 \mathrm{~nm}$. There exist a lot of elongated particles with the lengths varying from $900 \mathrm{~nm}$ to $100 \mathrm{~nm}$, as well as ellipsoid and circular pieces, on the surface of TF3 (Figure 4(c)).

Energy dispersive analysis of X-rays (EDAX) provides quantitative information about the composition of the thin films. The EDAX results about atomic percentages of $\mathrm{Cu}$ and $\mathrm{S}$ elements in TF1, TF2, and TF3 thin films are in close agreement with the X-ray diffraction (XRD) results (Table 2).

3.3. Atomic Force Microscopy Studies. The control of the surface properties is important in developing for the physical characteristics of the films. Atomic force microscopy (AFM) is used to determine nanoscale surface morphology of the deposited films. These AFM observations allow for controlling surface properties by changing film deposition parameters. Figure 5 shows three-dimensional (3D) AFM scans of the crystallized $\mathrm{Cu}_{x} \mathrm{~S}$ thin films grown by USP on glass substrates at 240,280 , and $320^{\circ} \mathrm{C}$. The images show that the surface topography is typical, and the morphology of the film indicates roughness and shaped crystallites [7, 31]. The surface rms roughness values of the TF1, TF2, and TF3 thin films are 54.0, 47.2, and $24.3 \mathrm{~nm}$, respectively. The average rms roughness of the films decreases remarkably as the film production temperature increases from $240^{\circ} \mathrm{C}$ to $320^{\circ} \mathrm{C}$. The increase in substrate temperature also brings about an increase in $\mathrm{Cu} / \mathrm{S}$ ratio of the films. The AFM images of the $\mathrm{Cu}_{x} \mathrm{~S}$ thin films represent the fact that each of the films 
TABLE 1: Comparison of observed XRD data of thin films with the JCPDS cards. The film thickness, lattice type, crystallite size calculated by Scherrer formula, and contact angle are also summarized.

\begin{tabular}{|c|c|c|c|c|c|c|c|c|c|c|}
\hline \multirow{2}{*}{ Thin film } & \multirow{2}{*}{ Film thickness (nm) } & \multicolumn{2}{|c|}{ Observed values } & \multicolumn{2}{|c|}{ Standard values } & \multirow{2}{*}{ hkl } & \multirow{2}{*}{ Phase } & \multirow{2}{*}{ Lattice } & \multirow{2}{*}{$\begin{array}{c}\text { Crystallite size } \\
\text { D (nm) }\end{array}$} & \multirow{2}{*}{$\begin{array}{c}\text { Contact angle } \\
\left({ }^{\circ}\right)\end{array}$} \\
\hline & & $2 \theta\left(^{\circ}\right)$ & $\mathrm{d}(\AA)$ & $2 \theta\left(^{\circ}\right)$ & $\mathrm{d}(\AA)$ & & & & & \\
\hline \multirow{5}{*}{ TF1 } & \multirow{5}{*}{160} & 27.74 & 3.22 & 27.68 & 3.22 & $\left(\begin{array}{lll}1 & 0 & 1\end{array}\right)$ & $\mathrm{CuS}$ & Hexagonal & \multirow{5}{*}{11.92} & \multirow{5}{*}{96.60} \\
\hline & & 29.48 & 3.03 & 29.28 & 3.05 & $\left(\begin{array}{lll}1 & 0 & 2\end{array}\right)$ & $\mathrm{CuS}$ & Hexagonal & & \\
\hline & & 31.76 & 2.80 & 31.79 & 2.81 & $\left(\begin{array}{lll}1 & 0 & 3\end{array}\right)$ & $\mathrm{CuS}$ & Hexagonal & & \\
\hline & & 48.24 & 1.89 & 47.94 & 1.90 & $\left(\begin{array}{lll}1 & 1 & 0\end{array}\right)$ & $\mathrm{CuS}$ & Hexagonal & & \\
\hline & & 59.64 & 1.55 & 59.35 & 1.56 & $\left(\begin{array}{lll}1 & 1 & 6\end{array}\right)$ & $\mathrm{CuS}$ & Hexagonal & & \\
\hline \multirow{4}{*}{ TF2 } & \multirow{4}{*}{380} & 28.16 & 3.18 & 27.95 & 3.19 & $\left(\begin{array}{lll}6 & 6 & 2\end{array}\right)$ & $\mathrm{Cu}_{1.765} \mathrm{~S}$ & Cubic & \multirow{4}{*}{10.80} & \multirow{4}{*}{107.83} \\
\hline & & 32.26 & 2.76 & 32.27 & 2.77 & $\left(\begin{array}{lll}10 & 0 & 0\end{array}\right)$ & $\mathrm{Cu}_{1.765} \mathrm{~S}$ & Cubic & & \\
\hline & & 46.46 & 1.95 & 46.21 & 1.96 & $\left(\begin{array}{lll}14 & 2 & 0\end{array}\right)$ & $\mathrm{Cu}_{1.765} \mathrm{~S}$ & Cubic & & \\
\hline & & 54.80 & 1.67 & 54.79 & 1.67 & $\left(\begin{array}{lll}15 & 7 & 1\end{array}\right)$ & $\mathrm{Cu}_{1.765} \mathrm{~S}$ & Cubic & & \\
\hline \multirow{4}{*}{ TF3 } & \multirow{4}{*}{172} & 27.92 & 3.18 & 27.95 & 3.19 & $\left(\begin{array}{lll}6 & 6 & 2\end{array}\right)$ & $\mathrm{Cu}_{1.765} \mathrm{~S}$ & Cubic & \multirow{4}{*}{9.60} & \multirow{4}{*}{96.97} \\
\hline & & 32.44 & 2.76 & 32.27 & 2.77 & $\left(\begin{array}{lll}10 & 0 & 0\end{array}\right)$ & $\mathrm{Cu}_{1.765} \mathrm{~S}$ & Cubic & & \\
\hline & & 46.62 & 1.95 & 46.28 & 1.96 & $\left(\begin{array}{lll}2 & 2 & 0\end{array}\right)$ & $\mathrm{Cu}_{2} \mathrm{~S}$ & Cubic & & \\
\hline & & 54.78 & 1.67 & 54.79 & 1.67 & $\left(\begin{array}{lll}15 & 7 & 1\end{array}\right)$ & $\mathrm{Cu}_{1.765} \mathrm{~S}$ & Cubic & & \\
\hline
\end{tabular}

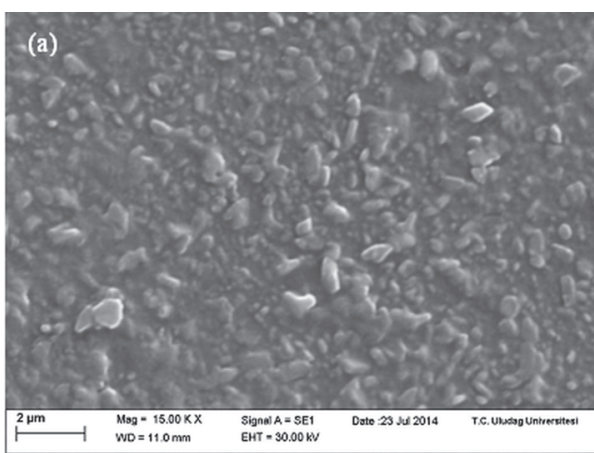

(a)

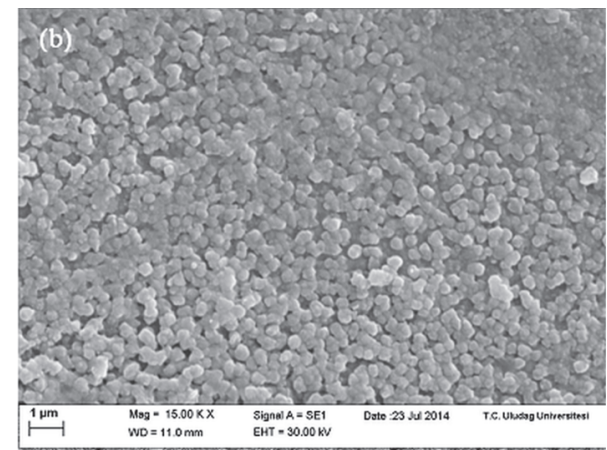

(b)

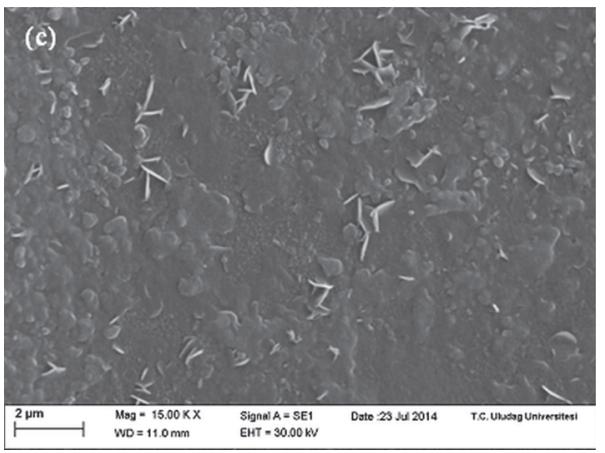

(c)

FIGURE 4: SEM micrographs of (a) TF1, (b) TF2, and (c) TF3.

is continuous and homogeneous and has no discontinuities or cracked areas (Figure 5).

3.4. Contact Angle Measurements. The contact angle is a macroscopic parameter, which is a consequence of the intermolecular interactions between a liquid and a solid in contact. Contact angle measurements are used to obtain information about the degree of these interactions. Figure 6 shows the photo-images of water contact angle measurements on the $\mathrm{Cu}_{x} \mathrm{~S}$ thin films and glass substrate. The water contact angle was equal to $25.76^{\circ}$ for untreated glass substrate (Figure 6(a)). The water contact angle measurements on TF1, TF2, and TF3 $\mathrm{Cu}_{x} \mathrm{~S}$ thin films were found to be $96.60^{\circ}, 107.83^{\circ}$, and $96.97^{\circ}$, respectively, which show hydrophobic nature of the films (Figures 6(b)-6(d)). The surface porosity of TF1 and TF3 is seen to be similar from the SEM and AFM images (Figures 


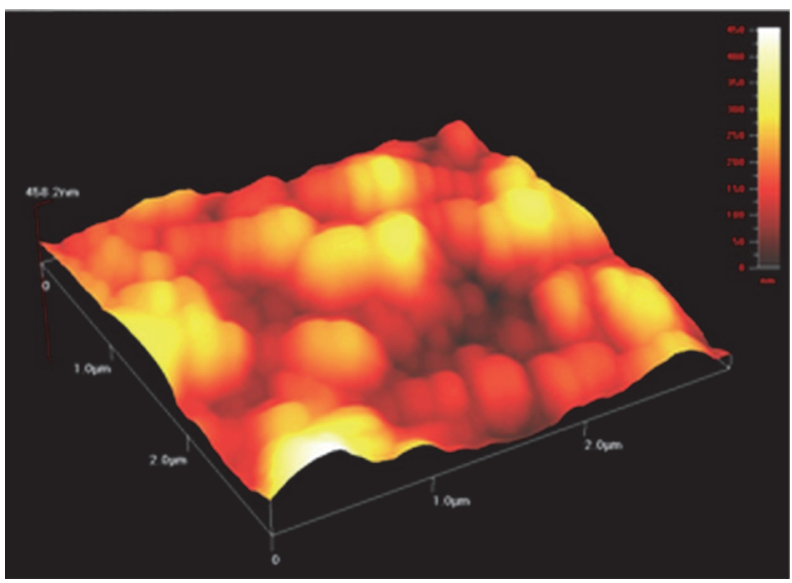

(a)

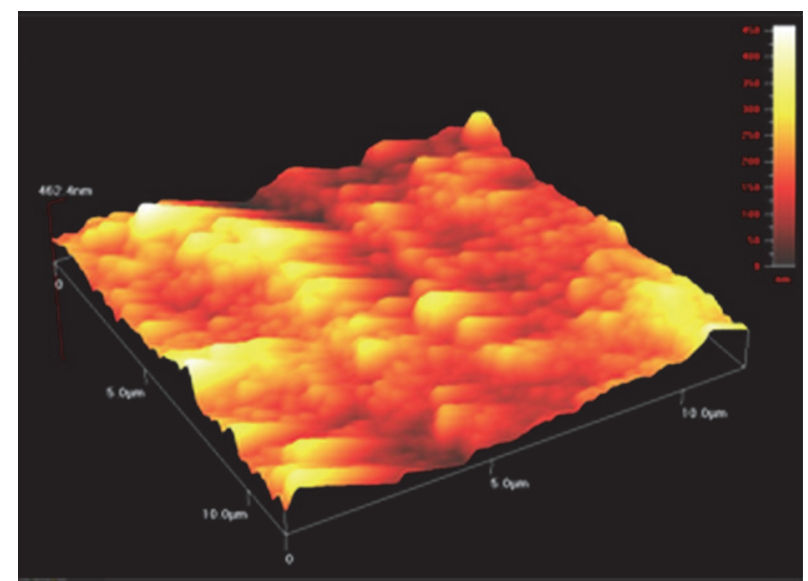

(b)

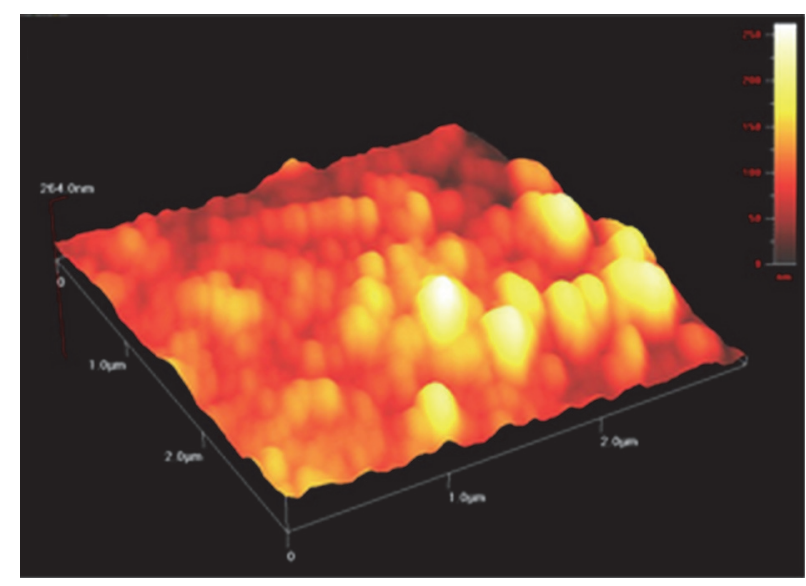

(c)

FIgURE 5: AFM image of (a) TF1, (b) TF2, and (c) TF3.

TABLE 2: Comparison of EDAX and XRD data.

\begin{tabular}{lccccc}
\hline Thin film & Element & $\begin{array}{c}\text { C norm. } \\
\text { (wt.\%) }\end{array}$ & $\begin{array}{c}\mathrm{C} \\
\text { error \% }\end{array}$ & $\begin{array}{c}\mathrm{Cu} / \mathrm{S} \\
\text { ratio } \\
\text { (EDAX) }\end{array}$ & $\begin{array}{c}\mathrm{Cu} / \mathrm{S} \text { ratio } \\
\text { (XRD) }\end{array}$ \\
\hline $\mathrm{TF} 1$ & $\mathrm{Cu}$ & 52.24 & 0.2 & 1.094 & 1.000 \\
\hline $\mathrm{TF} 2$ & $\mathrm{~S}$ & 47.76 & 0.2 & & \\
\hline \multirow{2}{*}{$\mathrm{TF} 3$} & $\mathrm{Cu}$ & 63.89 & 0.6 & 1.769 & 1.765 \\
& $\mathrm{Cu}$ & 36.11 & 0.5 & & \\
\hline
\end{tabular}

4 and 5). The contact angles are almost equal to each other for TF1 and TF3 due to this similarity. The surface of TF2 thin film is composed entirely of small and regular grains, while the surface of both TF1 and TF3 has not uniform grain structure. From SEM and AFM observations (Figures 4 and 5), it is concluded that the value of the contact angle is directly correlated with the nanoscale structure of film surfaces. As a result, TF2 has a highest contact angle value of $107.83^{\circ}$ due to its different surface topography.
3.5. Optical Properties. The optical transmittance spectra of $\mathrm{Cu}_{x} \mathrm{~S}$ films obtained for different deposition temperatures in the range of $200-1100 \mathrm{~nm}$ were shown in Figure 7 . The transmittance values of the films except for TF1 increase dramatically between 400 and $700 \mathrm{~nm}$ wavelength range. The results show that different deposition temperatures are effective on the optical and structural parameters of the films. As seen in XRD pattern of $\mathrm{Cu}_{x} \mathrm{~S}$ films (Figures 1-3), changing the deposition temperature results in occurrence of different $\mathrm{Cu}_{x} \mathrm{~S}$ phases. It was found that TF1, TF2, and TF3 films had an average $T$ value of $\sim 33 \%, 65 \%$, and $55 \%$ in the visible region, respectively. For TF2 and TF3 films, there is a significant increase in $T \%$ values depending on the deposition temperature. It is clear that the transmittance of the samples increases as the substrate temperature increases. The thicknesses of TF1, TF2, and TF3 are 160, 380, and $172 \mathrm{~nm}$, respectively. Thus, the film with higher thickness shows an increase in transmittance.

The optical band gaps $\left(E_{g}\right)$ for $\mathrm{Cu}_{x} \mathrm{~S}$ films were also studied and these values were determined using Tauc's law $[32,33]$ :

$$
\alpha h v=A\left(h v-E_{g}\right)^{m}
$$




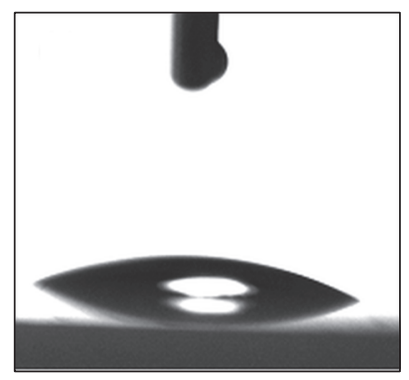

(a)

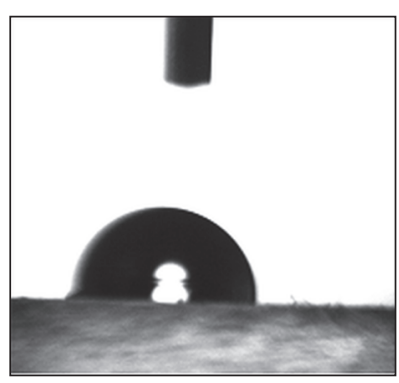

(b)

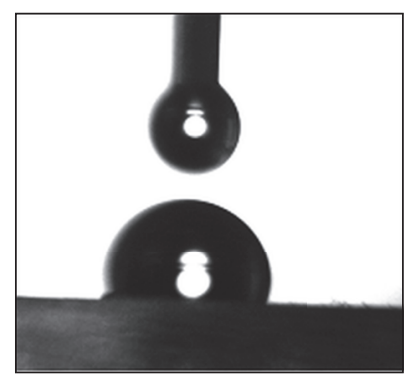

(c)

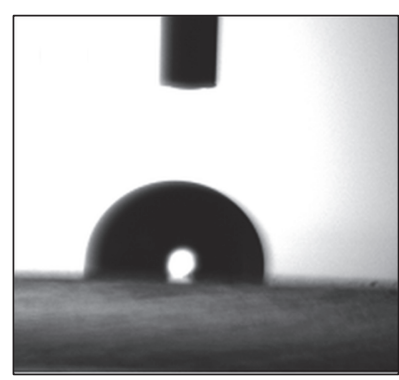

(d)

FIGURE 6: Droplet images of deionized water on (a) glass substrate, (b) TF1, (c) TF2, and (d) TF3.

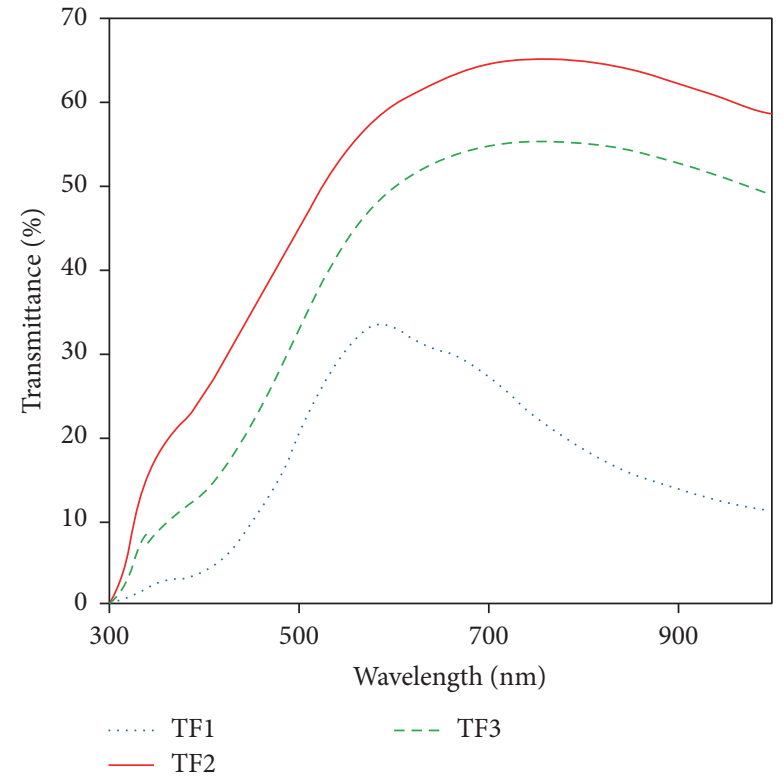

Figure 7: Optical transmission spectra of $\mathrm{Cu}_{x} \mathrm{~S}$ thin films.

Where $\alpha$ is the absorption coefficient, $h v$ is photon energy, $E_{g}$ is energy band gap, $A$ is the edge parameter, and $m$ is a constant for a given transition (the value of $m$ is $1 / 2$ for direct allowed transitions and 2 for indirect allowed transition).

Figure 8 shows plots of square of the product of the optical absorption coefficient $(\alpha)$ and photon energy $(h \nu)$ against photon energy. The values of the energy band gaps for the TF1, TF2, and TF3 films are 2.07, 2.50, and $2.28 \mathrm{eV}$, respectively. It was found that the energy band gaps of the films varied with not only deposition temperature but also $\mathrm{Cu}_{x} \mathrm{~S}$ phases. XRD pattern given in Figure 1 is evidence that TF1 thin film has $\mathrm{CuS}$ single phase, and the calculated energy band gap $\left(E_{g}\right)$ using experimental data for TF1 thin film is in agreement with the $E_{g}$ value reported by Grozdanov and Najdoski [34] and by Zhu et al. [29]. The XRD data shows that TF2 has single phase of $\mathrm{Cu}_{1.765} \mathrm{~S}$. There is no report of $E_{g}$ values for $\mathrm{Cu}_{1.765} \mathrm{~S}$ in the literature, but we have estimated that the $E_{g}$ value of $\mathrm{Cu}_{1.765} \mathrm{~S}$ is between $\mathrm{Cu}_{1.8} \mathrm{~S}(2.3 \mathrm{eV})$ [13] and $\mathrm{Cu}_{1.75} \mathrm{~S}$ $(2.54 \mathrm{eV})[12]$. The XRD pattern in Figure 3 demonstrates that TF3 thin film includes both $\mathrm{Cu}_{1.765} \mathrm{~S}$ and $\mathrm{Cu}_{2} \mathrm{~S}$ phases; that is, this film is a mixture of $\mathrm{Cu}_{1.765} \mathrm{~S}$ and $\mathrm{Cu}_{2} \mathrm{~S}$ phases. So,

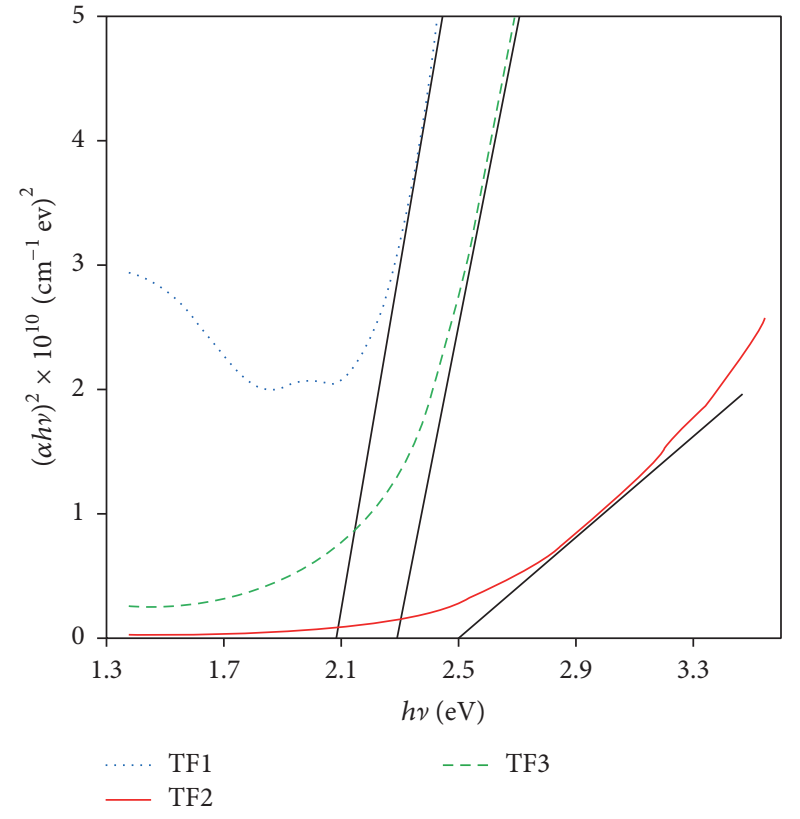

FIGURE 8: The plot of $(\alpha h \nu)^{2}$ versus photon energy, $h v$, for $\mathrm{Cu}_{x} \mathrm{~S}$ thin films.

there is a small decrease in $E_{g}$ value compared with TF2 thin film. The reason of this decrease for TF3 thin film may be attributed to having $\mathrm{Cu}_{2} \mathrm{~S}$ phase component $(1.5 \mathrm{eV})$ [15] in the mixed phase. Consequently, both optical and structural results found by evaluated experimental data for the films support each other.

3.6. Electrical Properties. Hall effect measurements were performed to characterize the electrical properties of the $\mathrm{Cu}_{x} \mathrm{~S}$ films and all the films showed a p-type semiconductor with hole concentration in the range of $(1.45-2.64) \cdot 10^{21} \mathrm{~cm}^{-3}$ and hole mobility (1.96-11.8) $10^{-3} \mathrm{~cm}^{2} / \mathrm{V} \cdot \mathrm{s}$. Carrier concentration, Hall mobility, Hall coefficient, and sheet resistance values were obtained by four-point probe technique using Hall effect measurement system in a magnetic field strength of $0.556 \mathrm{~T}$ and these values were listed in Table 3. As shown in Table 3, all the films present high sheet resistance of $(1.25-7.67) \cdot 10^{3}$ $(\Omega \mathrm{cm})^{-1}$. It is observed that the carrier mobility values of the films increase as the film crystallite size increases (Tables 1 
TABLE 3: Carrier concentration, Hall mobility, Hall coefficient, sheet resistance, and optical gap values of the $\mathrm{Cu}_{x} \mathrm{~S}$ thin films.

\begin{tabular}{lccccc}
\hline $\mathrm{Cu}_{x} \mathrm{~S}$ sample & $\begin{array}{c}\text { Carrier concentration } \\
\left(\times 10^{21} \mathrm{~cm}^{-3}\right)\end{array}$ & $\begin{array}{c}\text { Hall mobility } \\
\left(\mathrm{cm}^{2} / \mathrm{Vs}\right)\end{array}$ & $\begin{array}{c}\text { Hall coefficient } \\
\left(\times 10^{-4} \mathrm{~cm}^{3} / \mathrm{C}\right)\end{array}$ & $\begin{array}{c}\text { Sheet resistance } \\
\left(\times 10^{3} \Omega\right)\end{array}$ & $\begin{array}{c}\text { Optical gap } \\
(\mathrm{eV})\end{array}$ \\
\hline TF1 & 2.64 & $1.18 \times 10^{-2}$ & 4.42 & 1.25 & 2.07 \\
TF2 & 1.45 & $8.64 \times 10^{-3}$ & 1.56 & 1.29 & 2.50 \\
TF3 & 2.41 & $1.96 \times 10^{-3}$ & 2.35 & 7.67 & 2.28 \\
\hline
\end{tabular}

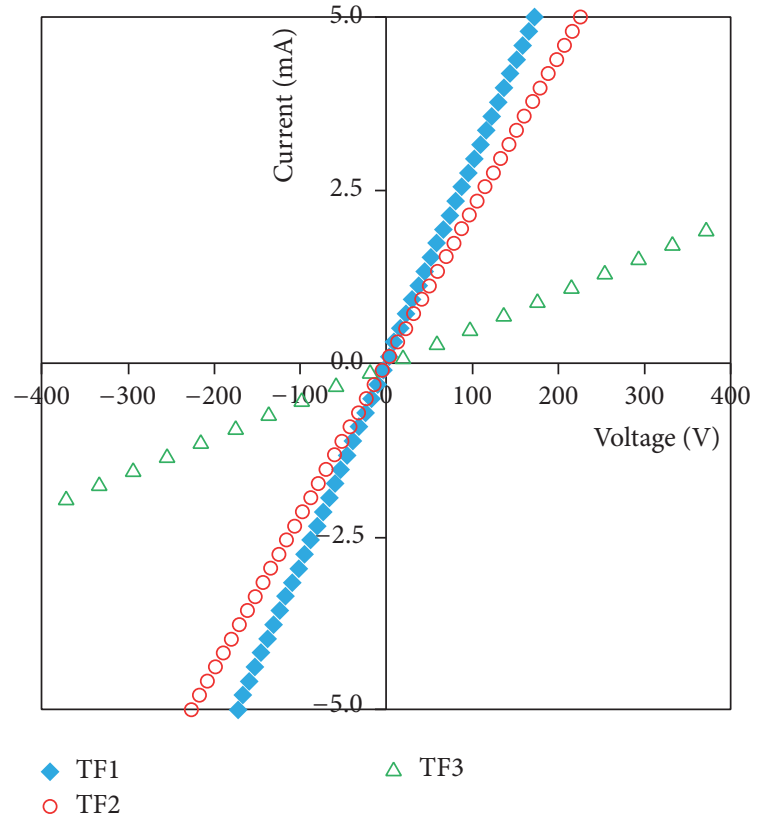

Figure 9: Current-voltage variations for copper sulphide thin films at room temperature.

and 3). It is in agreement with the study reported earlier about $\mathrm{Cu}_{x} \mathrm{~S}$ films [18]. The current-voltage $(I-V)$ curves of the films are obtained in dark (Figure 9). The current increases linearly with the voltage, as seen in Figure 9. Such differences in the $I-V$ curves of the films can be correlated with film thickness and/or with amount of defects.

\section{Conclusions}

Copper sulphide thin films were deposited onto glass substrate by spray pyrolysis technique at temperatures 240,280 , and $320^{\circ} \mathrm{C}$. It was found that crystalline phase, crystallite size, and surface uniformity of the films were very sensitive to the substrate temperature. The increase of substrate temperature caused crystallite size of the film to decrease by $11.92 \mathrm{~nm}$ to $9.60 \mathrm{~nm}$. The film phase was $\mathrm{CuS}$ at $240^{\circ} \mathrm{C}$ and $\mathrm{Cu}_{1.765} \mathrm{~S}$ at $280^{\circ} \mathrm{C}$. The copper sulphide thin film exhibited polycrystalline structure composed of $\mathrm{Cu}_{1.765} \mathrm{~S}$ and $\mathrm{Cu}_{2} \mathrm{~S}$ phases when substrate temperature reached $320^{\circ} \mathrm{C}$. AFM analysis showed that the surface rms roughness decreased from $54.0 \mathrm{~nm}$ to $24.3 \mathrm{~nm}$ with the increase of substrate temperature. Sheet resistance of the films increased depending on the increasing substrate temperature. From the optical studies, direct energy band gap values of the films were determined to vary between
2.07 and $2.50 \mathrm{eV}$. However, any information or data about dependency of optical band gap of the films on substrate temperature could not be found in the literature. In addition to this, optical band gap was found to be dependent on the film thickness and increased from 2.07 to $2.50 \mathrm{eV}$ when film thickness was increased from 160 to $380 \mathrm{~nm}$. The currentvoltage variations for $\mathrm{Cu}_{x} \mathrm{~S}$ thin films were determined to be linear. These films had a p-type semiconductor behavior.

$\mathrm{Cu}_{x} \mathrm{~S}$ thin films produced in this study can be used in heterojunction solar cells due to their good crystalline structure and energy band gap value matching well solar radiation. Spray pyrolysis deposition represents a low cost technique, allowing the development of large area thin films for solar energy conversion devices.

\section{Competing Interests}

The authors declare that there is not any conflict of interests.

\section{Acknowledgments}

This work was supported by the Research Fund of Uludag University Project no. OUAP(F)-2013/11. The authors would like to thank Uludag University for financial support. The authors wish to thank Assoc. Professor Dr. Salih Köse of Osmangazi University (Turkey) for allowing the use of ultrasonic chemical spray pyrolysis system in semiconductor film production laboratory.

\section{References}

[1] M. Orphanou, E. Leontidis, T. Kyprianidou-Leodidou, P. Koutsoukos, and K. C. Kyriacou, "Study of copper sulfide crystallization in PEO-SDS solutions," Langmuir, vol. 20, no. 13, pp. 5605-5612, 2004.

[2] M. Peng, L.-L. Ma, Y.-G. Zhang, M. Tan, J.-B. Wang, and Y. Yu, "Controllable synthesis of self-assembled $\mathrm{Cu} 2 \mathrm{~S}$ nanostructures through a template-free polyol process for the degradation of organic pollutant under visible light," Materials Research Bulletin, vol. 44, no. 9, pp. 1834-1841, 2009.

[3] J. Madarász, M. Okuya, and S. Kaneko, "Preparation of covellite and digenite thin films by an intermittent spray pyrolysis deposition method," Journal of the European Ceramic Society, vol. 21, no. 10-11, pp. 2113-2116, 2001.

[4] H. Lee, S. W. Yoon, E. J. Kim, and J. Park, "In-situ growth of copper sulfide nanocrystals on multiwalled carbon nanotubes and their application as novel solar cell and amperometric glucose sensor materials," Nano Letters, vol. 7, no. 3, pp. 778784, 2007.

[5] J.-S. Kim, D.-Y. Kim, G.-B. Cho et al., "The electrochemical properties of copper sulfide as cathode material for rechargeable 
sodium cell at room temperature," Journal of Power Sources, vol. 189, no. 1, pp. 864-868, 2009.

[6] A. A. Sagade, R. Sharma, and I. Sulaniya, "Enhancement in sensitivity of copper sulfide thin film ammonia gas sensor: effect of swift heavy ion irradiation," Journal of Applied Physics, vol. 105, no. 4, Article ID 043701, 2009.

[7] R. Sharma, A. A. Sagade, S. R. Gosavi et al., "Effect of high electronic energy loss of $100 \mathrm{MeV}$ gold heavy ions in copper chalcogenides ( $\mathrm{CuX}, \mathrm{X}=\mathrm{S}, \mathrm{Se})$ at nanoscale: opto-electronic properties study," Journal of Non-Crystalline Solids, vol. 355, no. 31-33, pp. 1653-1658, 2009.

[8] D. J. Chakrabarti and D. E. Laughlin, "The Cu-S (CopperSulfur) system," Bulletin of Alloy Phase Diagrams, vol. 4, no. 3, pp. 254-271, 1983.

[9] R. J. Goble, "Relationship between crystal structure, bonding and cell dimensions in the copper sulfides," Canadian Mineralogist, vol. 23, no. 1, pp. 61-76, 1985.

[10] A. E. Raevskaya, A. L. Stroyuk, S. Y. Kuchmii, and A. I. Kryukov, "Catalytic activity of CuS nanoparticles in hydrosulfide ions air oxidation," Journal of Molecular Catalysis A: Chemical, vol. 212, no. 1-2, pp. 259-265, 2004.

[11] A. A. Sagade and R. Sharma, "Copper sulphide $\left(\mathrm{Cu}_{x} \mathrm{~S}\right)$ as an ammonia gas sensor working at room temperature," Sensors and Actuators, B: Chemical, vol. 133, no. 1, pp. 135-143, 2008.

[12] M. Behboudnia and B. Khanbabaee, "Investigation of nanocrystalline copper sulfide $\mathrm{Cu}_{7} \mathrm{~S}_{4}$ fabricated by ultrasonic radiation technique," Journal of Crystal Growth, vol. 304, no. 1, pp. 158$162,2007$.

[13] A. V. Naumov, V. N. Semenov, A. N. Lukin, and E. G. Goncharov, "Phase composition of copper sulfide films produced from copper salt-thiourea complexes," Inorganic Materials, vol. 38, no. 3, pp. 271-273, 2002.

[14] Y. Rodríguez-Lazcano, H. Martínez, M. Calixto-Rodríguez, and A. Núñez Rodríguez, "Properties of CuS thin films treated in air plasma," Thin Solid Films, vol. 517, no. 21, pp. 5951-5955, 2009.

[15] X. Yu and X. An, "Controllable hydrothermal synthesis of $\mathrm{Cu}_{2} \mathrm{~S}$ nanowires on the copper substrate," Materials Letters, vol. 64, no. 3, pp. 252-254, 2010.

[16] S. Schneider, J. R. Ireland, M. C. Hersam, and T. J. Marks, "Copper(I) tert-butylthiolato clusters as single-source precursors for high-quality chalcocite thin films: film growth and microstructure control," Chemistry of Materials, vol. 19, no. 11, pp. 2780-2785, 2007.

[17] Y. Yamamoto, T. Yamaguchi, T. Tanaka, N. Tanahashi, and A. Yoshida, "Characterization of $\mathrm{CuInS}_{2}$ thin films prepared by sputtering from binary compounds," Solar Energy Materials and Solar Cells, vol. 49, no. 1-4, pp. 399-405, 1997.

[18] C. N. De Carvalho, P. Parreira, G. Lavareda, P. Brogueira, and A. Amaral, "P-type $\mathrm{Cu}_{x} \mathrm{~S}$ thin films: integration in a thin film transistor structure," Thin Solid Films, vol. 543, pp. 3-6, 2013.

[19] A. Isac, A. Duta, A. Kriza, A. Enesca, and M. Nanu, "The growth of CuS thin films by Spray Pyrolysis," Journal of Physics: Conference Series, vol. 61, no. 1, pp. 477-481, 2007.

[20] S. Schneider, Y. Yang, and T. J. Marks, "Growth of highly oriented chalcocite thin films on glass by aerosol-assisted spray pyrolysis using a new single-source copper thiolate precursor," Chemistry of Materials, vol. 17, no. 17, pp. 4286-4288, 2005.

[21] C. Naşcu, I. Pop, V. Ionescu, E. Indrea, and I. Bratu, "Spray pyrolysis deposition of CuS thin films," Materials Letters, vol. 32, no. 2-3, pp. 73-77, 1997.
[22] N. Mukherjee, A. Sinha, G. G. Khan, D. Chandra, A. Bhaumik, and A. Mondal, "A study on the structural and mechanical properties of nanocrystalline $\mathrm{CuS}$ thin films grown by chemical bath deposition technique," Materials Research Bulletin, vol. 46, no. 1, pp. 6-11, 2011.

[23] L. Isac, A. Duta, A. Kriza, S. Manolache, and M. Nanu, "Copper sulfides obtained by spray pyrolysis-possible absorbers in solid-state solar cells," Thin Solid Films, vol. 515, no. 15, pp. 57555758, 2007.

[24] W.-Y. Kim, B. M. Palve, H. M. Pathan, and O.-S. Joo, "Spray pyrolytic deposition of polycrystalline $\mathrm{Cu}_{2} \mathrm{~S}$ thin films," Materials Chemistry and Physics, vol. 131, no. 1-2, pp. 525-528, 2011.

[25] S.-Y. Wang, W. Wang, and Z.-H. Lu, "Asynchronous-pulse ultrasonic spray pyrolysis deposition of $\mathrm{Cu}_{x} \mathrm{~S}(\mathrm{x}=1,2)$ thin films," Materials Science and Engineering B, vol. 103, no. 2, pp. 184-188, 2003.

[26] E. Elangovan and K. Ramamurthi, "A study on low cost-high conducting fluorine and antimony-doped tin oxide thin films," Applied Surface Science, vol. 249, no. 1-4, pp. 183-196, 2005.

[27] N. L. Tarwal, V. V. Shinde, A. S. Kamble et al., "Photoluminescence and photoelectrochemical properties of nanocrystalline $\mathrm{ZnO}$ thin films synthesized by spray pyrolysis technique," Applied Surface Science, vol. 257, no. 24, pp. 10789-10794, 2011.

[28] F. Atay, V. Bilgin, I. Akyuz, and S. Kose, "The effect of In doping on some physical properties of CdS films," Materials Science in Semiconductor Processing, vol. 6, no. 4, pp. 197-203, 2003.

[29] L. Zhu, Y. Xie, X. Zheng, X. Liu, and G. Zhou, "Fabrication of novel urchin-like architecture and snowflake-like pattern CuS," Journal of Crystal Growth, vol. 260, no. 3-4, pp. 494-499, 2004.

[30] B. D. Cullity, Elements of X-Ray Diffraction, Addison-Wesley Publishing Company Inc, Reading, Mass, USA, 1st edition, 1956.

[31] L. Isac, L. Andronic, A. Enesca, and A. Duta, "Copper sulfide films obtained by spray pyrolysis for dyes photodegradation under visible light irradiation," Journal of Photochemistry and Photobiology A: Chemistry, vol. 252, pp. 53-59, 2013.

[32] A. U. Ubale, D. M. Choudhari, J. S. Kantale et al., "Synthesis of nanostructured $\mathrm{Cu}_{x} \mathrm{~S}$ thin films by chemical route at room temperature and investigation of their size dependent physical properties," Journal of Alloys and Compounds, vol. 509, no. 37, pp. 9249-9254, 2011.

[33] J. I. Pankove, Optical Processes in Semiconductors, Prentice-Hall Inc, Englewood Cliffs, NJ, USA, 1971.

[34] I. Grozdanov and M. Najdoski, "Optical and electrical properties of copper sulfide films of variable composition," Journal of Solid State Chemistry, vol. 114, no. 2, pp. 469-475, 1995. 

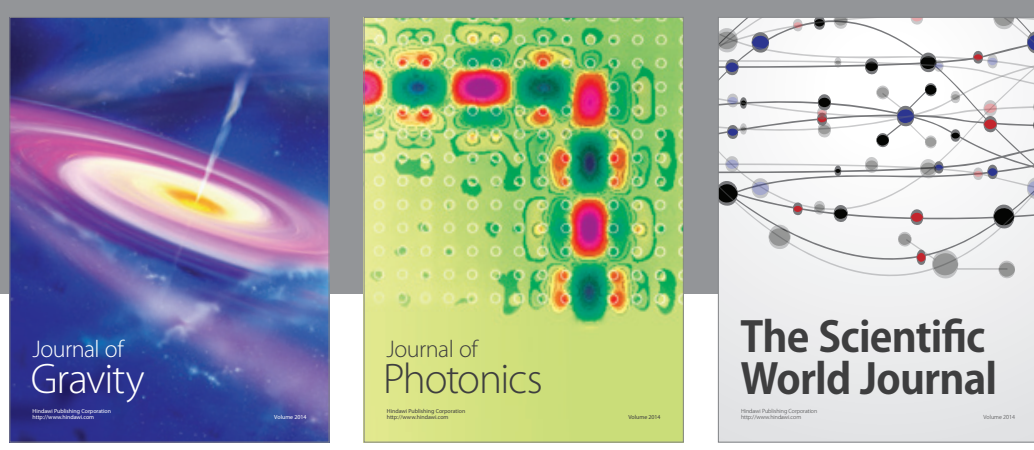

The Scientific World Journal
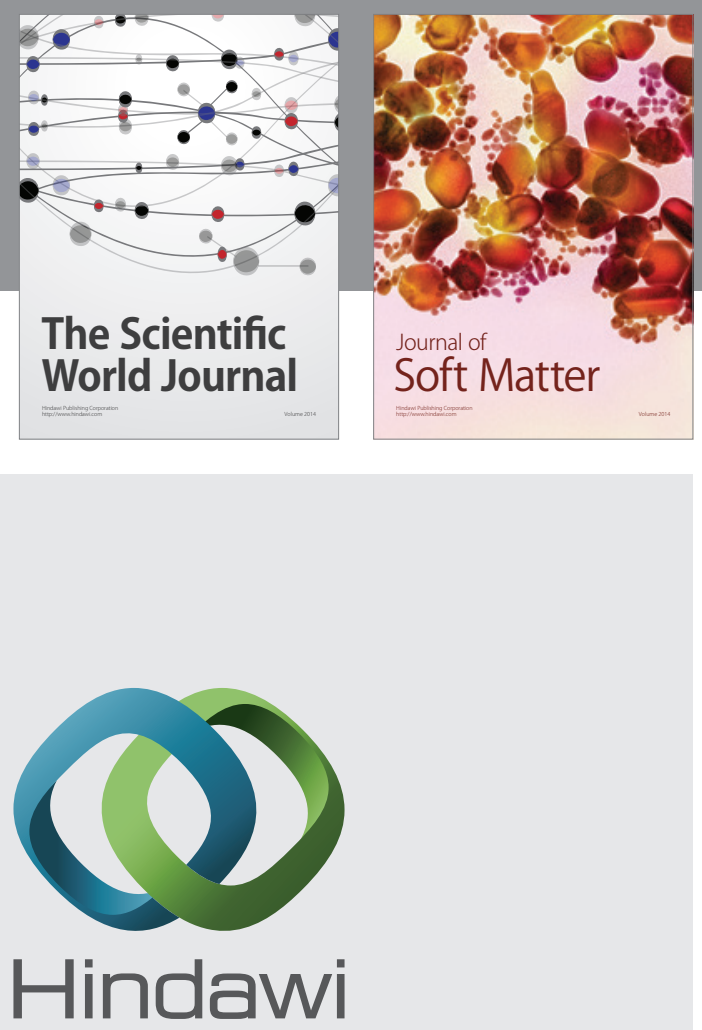

Submit your manuscripts at

https://www.hindawi.com
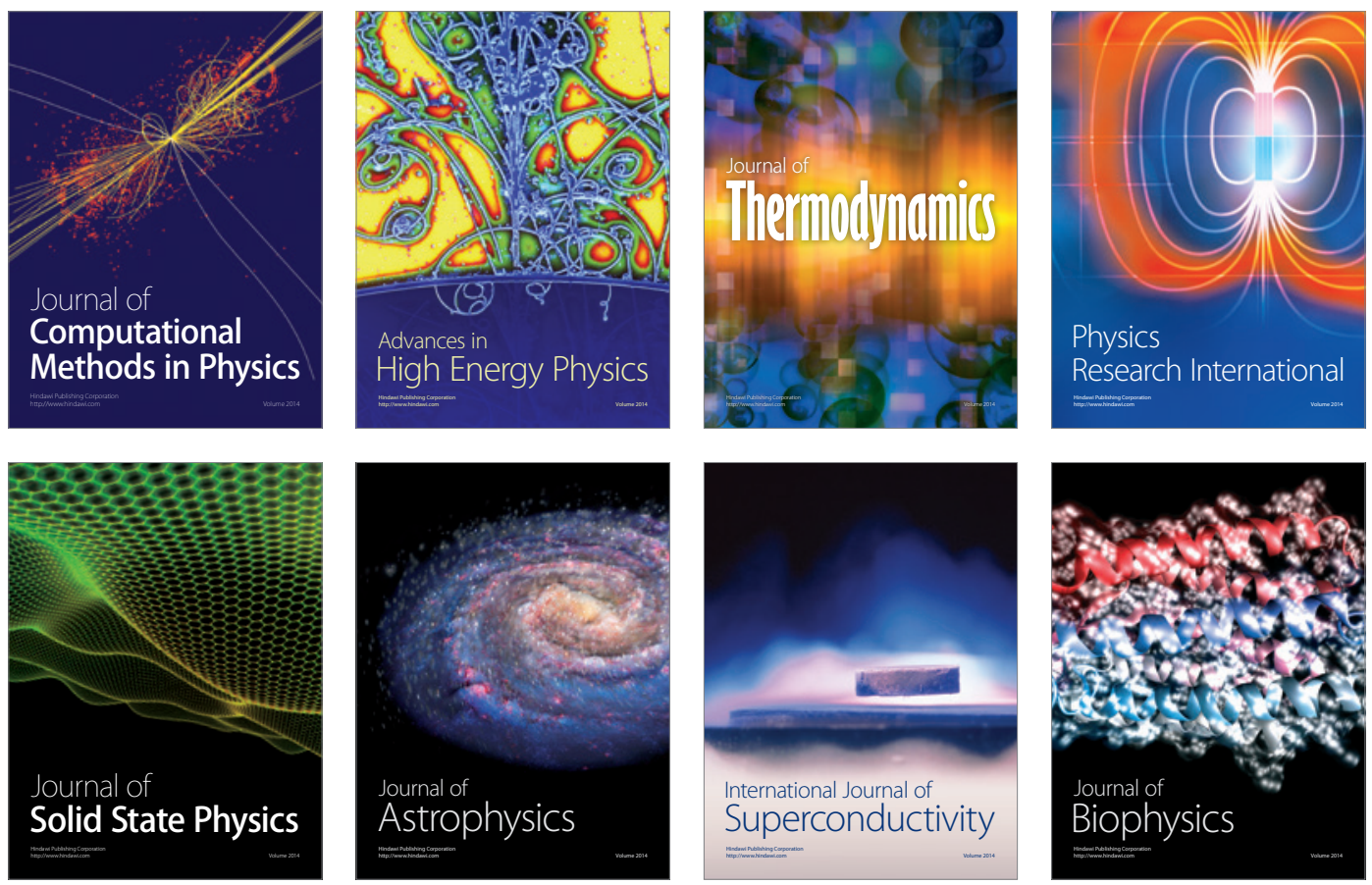
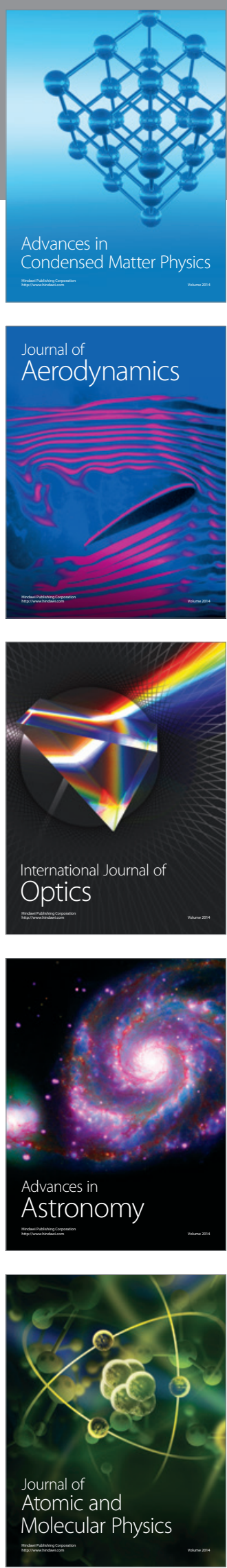